\title{
A Study on Public Service of Convention and Exhibition in the Internet + Era: a Case Study from the CITM in Kunming in 2015
}

\author{
Xie Hongzhong* \\ School of Tourism and Hospitality \\ Yunnan University of Finance and Economics \\ China \\ (1057717852@qq.com)
}

\author{
Huang Lijia \\ School of Tourism and Hospitality \\ Yunnan University of Finance and Economics \\ China \\ (1204101464@qq.com)
}

\begin{abstract}
In the era of the Internet+, with the constant updating of new technologies and more and more software and hardware systems are being applied into public service of convention and exhibition industry, which obtains great leaping development. Every coin has two sides, along with the new technologies come lots of self-invited troubles to the advancement of convention and exhibition industry, and customization is just one of the cures to these problems. This article takes the example of the China International Travel Mart in Kunming in 2015 and puts forward a relatively simple customization plan to realize the efficient and ordered management of this CITM.
\end{abstract}

Keywords-the Internet+; convention and exhibition industry; customization; CITM; public service

\section{INTRODUCTION}

Convention and Exhibition industry is an important component of modern service industry, and integrates commodity display and trade, cooperation between economy and technology, intercourse of science and technology. Convention and Exhibition industry has many functions, such as, the accelerator of economic growth, the booster of city development, the spreader of city image and the absorption machine of employment. The huge crowds, material flow, capital flow and information flow converged by convention and exhibition activities not only play an important role in enlarging trade, introducing technology, attracting investment, developing high-tech industry and promoting economic cooperation and cultural exchange etc but also takes an irreplaceable responsibility in improving city taste and fame and developing economy and society fast and well ${ }^{[1]}$. In the Internet + age, by using Internet mobile technology, convention and exhibition industry are bonded closely with lots of industries, such as catering, lodging, transportation, entertainment, advertising, and logistics and so on ${ }^{[2]}$.

The internet + stands for a new kind of economic pattern, which gives full play to Internet in optimizing and integrating role in the allocation of factor of production, and integrates deeply the innovative achievements of Internet and all fields of economic society and improves the creativity and productivity of the real economy and creates a new form of economic development that is based on the Internet. Simply speaking, the Internet + is exactly the Internet plus each traditional industry, however it is not a simple addition but by using the Internet platform and ICT (information and communication technology) to merge thoroughly the Internet and traditional industries and create new ecology of development. "+" means trans-boundary, revolution, openness and reshaping. The technology of the Internet + can bring remarkable changes to all areas, especially to MICE which has the characters of highly integrated of information-based and Customization. The specific changes are the mutual cooperation and integration between the Internet and MICE and the connection with the business and projects and principal organization and participants and anything else that are concerned with $\mathrm{MICE}^{[3]}$. The technologies of the Internet + are given such as Conference Management System, which offers effective links between users and conferences, Virtual Reality, "Kaikaihui" Wi-Fi enhancement solutions, iBeacon, which offers the both online and offline interactive experience between exhibitors and visitors, meetings business docking system etc.

\section{ChancES OF CONVENTION AND EXHIBITION INDUSTRY CAUED BY THE INTERNET TECHNOLOGY}

The development of the times is just like a galloped forward train, if one can't be the one in that train, one can just be a view of the people in the train. We are now in a time of change, all walks of life is experiencing earthshaking changes, so does the convention and exhibition industry. Under the influence of emerging technology and Internet thinking, the traditional convention and exhibition industry will realize leaping development in the direction of efficiency and intelligence. The changes on convention and exhibition industry produced by Internet technology can be elaborated generally from three aspects: the management of exhibition information and affairs, the experience and interaction on site, the marketing and propagating of the exhibition.

\section{A. Technologies about the management of the information of the exhibition \\ In the era of the Internet+, the management of the exhibition information becomes more efficient, more systematic and more convenient. The first one called "Kaikaihui" Wi-Fi enhancement solutions ${ }^{[4]}$, which can on one}


hand enhance Wi-Fi network without increasing the large relevant equipment, on the other hand, make sure the stability of the Wi-Fi, so the participant can enjoy themselves whenever and wherever they want. The second named Meetings Business Docking System which works on the platform of WeChat, which assists with the reservation, the negotiation and the audition between the buyers and the sellers, who need to scan the certain two-dimensional code to end to business. There are also many other management systems like the system of the management of smart seats, Conference business social networking solutions and so on.

\section{B. Technologies about intercourse and experience on spot}

The tip on site ${ }^{[5]}$, an interaction product used in conferences, meetings and high-end training, and its prototype comes from a creative mode called " free class, tip on spot", which was came up with by professor Li Shanyou, who comes from the Subversion-style Club. Its basic pattern is that if a trainee or participant supposes the speech given by the speaker is valuable and useful, then the listener can use the mobile terminals to give the speaker a tip on spot. The tip on spot system, working as an interaction tool, takes full advantage of the Internet technology, makes the trainee or participants to show the speakers their appreciation, admire, support, and inspire the tipping passion of the trainees or participants by using a large scale design of sense of experience. This system, not just offers a very convenient payment channel but adds lots of fun to life, has been widely used in these scenarios that need intercourse and to pay the bill on spot like charity activity, live action, ordering and so on.

As a new generation convention and exhibition service APP, Zhan Lantong ${ }^{[6]}$, which offers convention and exhibition service a suitable interactive platform and substantially reflect the superiority of the smart mobile terminal. Usually, the purchasers joined exhibition, obtain the information though advertisement, leading board, enter into the exhibition along with the crowds, exchange cards and take some documents, so the information they acquired are in disorder, and this phenomenon can be altered by Zhan Lantong APP. On one hand, to customers, the smart navigation of this APP helps with the quick understanding of the layout of the exhibition and makes it more convenient to find out the special exhibitors and exhibits and assists with the electronic interactive with the interested exhibitors and achieving valuable information. On the other hand, the exhibitors can understand the tastes of the customers though this APP, and target the potential or existing customers precisely.

\section{Technologies about exhibition marketing}

Digital Listen System ${ }^{[7]}$, a patent technology, extracts the key words from the whole social media and the Internet digital media every 5 seconds and detects in real time the volume, emotion, public sentiment of the users and the most popular words among the users to realize the watching effects according to the settings and rules deploying of the key words, and last but not least, recognize challenges and opportunities. Currently, it has been fully utilized in the China Open, the Global Mobile Internet Conference, China Beijing International High - Tech Expo, conference and convention and exhibition and so on. Digital Listen System functions at the primary stage, middle stage and later stage of any marketing activity: Previous market investigation and research; public sentiment monitoring, operation guiding and the possible crisis counseling during the marketing activity; data report and performance rating of the whole marketing at the later phase.

\section{Troubles of CONVENTION AND EXHIBITION INDUSTRY CAUSED BY INTERNET TECHNOLOGY}

\section{A. The solutions are not comprehensive}

Currently, it is no secret to convention and exhibition projects sponsors that the mobile terminal supplies efficient and convenient services to the customers, but unfortunately, due to the ignorance of the exhibition process the solutions provided by the technology side always don't work out as expectations. Beyond all doubt, with the rapid developing of convention and exhibition industry, it captures the attention of a growing number of mobile technology Internet groups. Subsequently, numerous solutions and Apps are flooding into convention and exhibition industry successively. Since different convention and exhibition projects require different service, the solutions provided are generally customized, which means that one simple solution is not suitable for many of the convention and exhibition projects. In addition, thanks to the incomprehension of the convention and exhibition parties to technologies and the ambiguity of expressing their technical requirements, a translator, who understands the Internet technologies as well as the process of convention and exhibition, is generated spontaneously. Regretfully, these kinds of talents are very difficult to find out.

\section{B. Technology updates faster than market demands}

Anthropomorphic speaking, the encounter between Internet technology and convention and exhibition industry is lacking of sense of romance, which implies that the technology party offers the most advanced technologies wishfully, and overlooks the actual demands of the convention and exhibition projects. For example, in the summit of the "mobile Internet + convention and exhibition" in 2015, Iflytek CO., LTD, a company which specializes in studying on intelligent voice and speech technologies, developing of software and chips etc. ) launched a active ticket management solution-face identification. However, this solution has triggered a fierce debate in convention and exhibition industry, which focuses on how to make the face identification precise enough, and what if it results in a large number of customer stagnation, which may influence the order of the exhibition even lead to accidents and chaos.

\section{Technology gives away the business secretes of the exhibitor}

According to the book On meeting industry, published by China Commerce and Trade Press and written by General Manager of China National Convention Center Liu Haiying and Deputy General Manager of China National Convention Center $\mathrm{Xu}$ Feng, a successful meeting destination should 
include six ingredients: accessibility, infrastructure, safety, CVB, reception capacity and service quality and attractions. During all these six ingredients, the safety means the physical security and property safety as well as the business secretes safety of the participants and the exhibitors. It is transparently enough that an exhibition is about to be a failure if it cannot ensure the comprehensive safeties. For example, to the entrance of the High moral map (a navigational system) into convention and exhibition industry and the slogan of smart indoor and outdoor navigation, make the business easier, many people express a concern, if the navigational system is allowed to get into the exhibition, how to ensure the safety of the business secretes.

\section{Customization of Convention AND EXHIBITION}

Faced with the troubles that given by technologies, the solution, customization, is put forward.

\section{A. Why customization}

On the macro level, the changes of the consumption market and the advancement of technology require the customization of convention and exhibition industry, on the micro level, different exhibition project requests different service and the exhibition psychology of the exhibitors and the participants also need customization.

The consumption market is transferring from the past simply having adequate food and clothing to comfortable type and creative type, and is featured by more and more people are stuffed. Take the example of MICE market, the people we serve are generally in the phase of transferring from comfortable type to creative type.

What is creative consumption? Well, it is featured by that a growing number of consumptions are no longer necessary, in other words, non-consuming does affect people's biological living. Under this condition, the consumption of people is just for the things such as entertainment, social intercourse, emotion and so on. It is transparently that the consumption of simply having adequate food and clothing is quiet easy to meet, while the creative consumption is different because even the consumer can't tell what they really need. Consequently, the demand of the future market, which is not really existed in this world, is created by the imagination of the people. The progressing of technology and the developing of the convention and exhibition industry is capturing the eyes of a growing number of technology enterprises, and subsequently, numerous solutions and Apps are pouring into convention and exhibition industry successively. Since different convention and exhibition projects require different service, hence customization.

On the other hand, based on the conference psychology, which can be divided into two parts, one is mass human psychology of conference and the other is meeting scene psychology. The first is relatively easy, for example, people like fashionable and amusing things, yearn for places that are with fine scenery, comfortable temperature and fresh air, enjoy travelling, leisure, entertainment, delicious food, health preserving and so on, so do the Participants. So if these things above can be combined with the meetings, it will make the meeting quite successful, lively and interesting. The second one called meeting scene psychology means in different scenarios, people's psychological feeling is different. Different psychological feelings will produce the different effectiveness of the meeting. In other word, in order to achieve the objectives of the meeting, the meeting planners can use the design and construction of the scene to adjust the psychology of the participating groups to a desired state.

\section{B. How customization}

Simply speaking, customization means satisfying the request of the consumers, and offers customized products and services. To accomplish customization, not only the requirements of the customer have to be met but some principles should be followed.

\section{1) customization="popularization + "}

With the base of popularization, something unique is decorated then the customization forms. For example, the customization of car is printed with distinguished color and so on; the customization of high-end tourism keeps the basic framework of catering, lodging, transportation, travelling and entertaining and changes only one or two part of the tourism; and the customization of the convention and exhibition will not necessarily to change all the details.

\section{2) transformation of thinking model}

The most fundamental difference between customization and popularization not lies in the changes of superficial expression but in the variation of thinking, which transforms from product-oriented to customer-oriented, an attitude of providing whatever the customer needs. The customization will not be far away if the thinking model is reversed.

\section{3) paying more attention to intercourse}

Consumers, without intercourse is called customer, otherwise called users. The interaction with customers is important and necessary because without the participation of the customer, the customization is just an empty promise. In the Internet age, there is a great chance that the customers can join the reach and develop of the products and services.

\section{A case \\ Case brief introduction:}

Launched in 1998, China International Travel Mart (abb. CITM) is a tourism trade and cooperation platform with the largest scale, the most influential and the greatest international and is held alternately by Shanghai and Yunnan annually. The 2015 CITM cosponsored by National Tourism Administration, Civil Aviation Administration of China and Yunnan Provincial Government, has been held in Kunming Dianchi International Convention and Exhibition Centre from $13^{\text {th }}$ to $15^{\text {th }}$ November 2015, with the theme of the travel along the Silk Road. The square of the exhibition of the mart is about 70 thousands square meters, which is 20 thousands square meters larger than the mart in 2013; and the number of the booth of the exhibition is 3087, with 412 booths from aboard, 1260 booths from Yunnan and 1415 booths from other place of China, reached a new high among the previous CITM in 
Yunnan. The number of the exhibiting countries and regions is 105 , which is also more than in previous years. The total number of the certified exhibition groups is 152, with 92 from aboard, 61 percent, 31 from regions, 21 percent, 28 individual exhibitors, 18 percent. India is the country of honor of this mart, with 1000 purchasers who come from South Korea, Japan, Russia, the United State, Europe, Hong Kong, Macao and Taiwan.

The design of the exhibition booth in the CITM 2015 emphasizes the characters of the Internet era, from the many kinds of multimedia equipments to the interesting interactive devices, all of this are telling the influence and changes of the Internet on tourism, the Internet + tourism makes the travelling easier, more free and more funny.

\section{Schedule:} 2015.

Certification and Installation: from $11^{\text {th }}$ to $12^{\text {th }}$ November 2015.

Presentation and transaction: from $13^{\text {th }}$ to $15^{\text {th }}$ November

Moving out exhibits: $16^{\text {th }}$ November 2015.

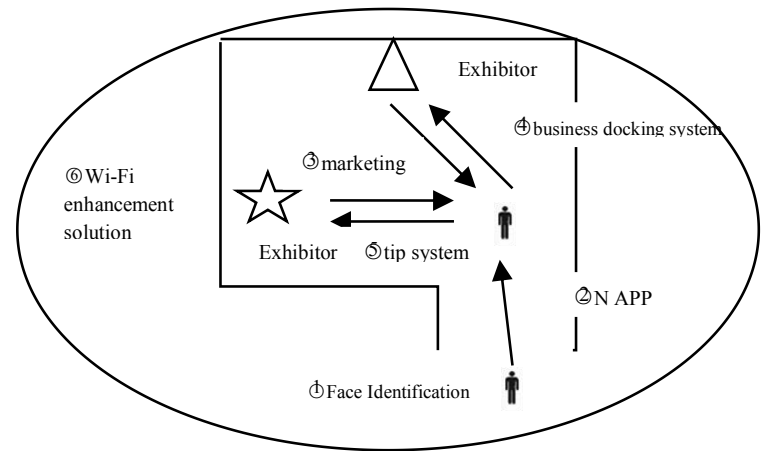

Fig 1 flow chart

Elaboration: seen from fig 1

Firstly, the face identification helps with the management of the ticket system and ensures the safety of the exhibition, because not anyone with a ticket can enter into the venue, for example, one who is a criminal will be stopped at the entrance.

Secondly, the navigation APP provides a short cut to some certain exhibitor and at the same offers many kinds of other information such as the introduction of the products, the layout of the venue and so on.

Thirdly, marketing system helps the exhibitor to market their product, collect data etc.

Fourthly, docking system, supported with powerful payment platform, assists the transaction between the exhibitors and the customers.

Fifthly, tip system is an intercourse software, and makes the communication more fascinating and diminishes the distance between the exhibitors and the customers.

The last but not the least, all these systems function in the support of the Wi-Fi enhancement solution.

\section{CONCLUSION}

Along with the continuously developing of the convention and exhibition industry, the increasing variation of the demands of customers, and the constantly updating of the new technologies, a growing number of troubles and concerns are coming, with the popularization of customization, these problems will be solved gradually. In a word, in the age of the Internet+, convention and exhibition will become more creative and interesting.

\section{REFERENCES}

[1] Ma Yong. Interpretation of the development of exhibition economy in China [J]. Economic geography, 2002, 22 (3). (In Chinese)

[2] Chen Ming. Discussion on the development of China MICE[J]. Business Research, 2006, (15):21-25. (In Chinese)

[3] Xie hongzhong.MICE activity analysis based on the view of service trade[M]. Forum on the Development of Yunnan,2010:p497-500, 2010 (In Chinese)

[4] http://mt.sohu.com/20150810/n418498773.shtml

[5] http://www.31huiyi.com/newslist/article/5462

[6] http://www.huaxia.com/xj-tw/xjxw/2014/07/3965771.html

[7] http://www.iblacktree.com/pro.html\#listen 